too many children for the working population to be able to afford to educate them in the way we would wish ? This is just one example that could be extended to our other social services. We cannot hope to provide adequate facilities if the proportion of our non-productive population is too large.

Man by his cleverness has been able to control his environment in many ways. It soems little to ask that he should control his rate of breeding. We need a crusade for the two child family and the government could go a long way to encourage this. Nobody, least of all a biologist, is going to ask his follow beings to forgo the pleasures of children. This is not necessary. Two children per adult female would go a long way towards stabilizing the popula. tion and may result in a rapid overall decrease. The advantages to the children would be enormous, for more of them would at least stand the chance of obtaining enough parental attention and care.

$$
\begin{aligned}
& \text { Yours faithfully, } \\
& \text { PegGY ELIIs }
\end{aligned}
$$

64 Blenheim Road,

Caversham,

Reading.

\section{Leonid Meteor Shower}

Sir,-I would like to refer to the article "Few Leonids Expected" (Nature, 224, 639; 1969). I had the wonderful experience of observing the Leonid meteor shower in November 1933 at Ste Radégonde near Tours, France, from the terrace of the Château de Chatenay. This was destroyed during the war, but owned until recently by the Reuter family of which several still living members observed the meteors with me during dinner timearound 8 p.m., on a beautiful clear evening, the exact date of which I caunot now confirm from my notesNovember 17 being a definite possibility. The meteors came so fast that $\mathrm{I}$, too, would venture to say that we saw 1,000 per minute, all coming from a vaguely northeasterly part of the sky falling southward. The phenomenon lasted so long that Mme Reuter-now long deadinsisted on our returning indoors to finish our meal, but there were still some meteors falling long after we had first noticed the shower, watched it for at least 10 minutes, returned indoors and went outside again after perhaps another 15 or even 20 minutes. I have never in all my life watched a similarly impressive natural phenomenon.

$$
\text { Yours faithfully, }
$$

Alfred E. Laurence

92 Higher Drive,

Purley, Surrey, CR2 2HJ.

\section{Cyclamates}

SIR,-In the leading article in Nature (224, 298; 1969), we find the somewhat startling statement that the indue. tion of chromosome breakage in leucocytes by cyclamates, though "ominous", is ". . . meaningless, because no one yet knows what harm, if any, damaged leucocyte chromo. somes do". It may be true that no one knows precisely what harm chromosome breakage may do, but it is well known (see, for example, Nature, 217, 507; 1968) that mutagenic and carcinogenic agents frequently cause chromosome breakage. We should like to draw attention to a recent article by Logator et al. (Science, 165, 1139; 1969) which describes the induction of chromosome breaks in rat spermatogonial cells following injection of low doses ( $1 \mathrm{mg} / \mathrm{kg}$ over a 5 day period) of a cyclamate metabolite, cyclohexylamine. Oser et al. (Nature, 220, 178; 1968) summarize the evidence for the conversion of cyclamates to cyclohexylamine in man, and present new evidence for this conversion in rats. In either case, since muta. genicity and carcinogenicity are the questions under discussion, would it not be reckless to allow continued consumption of cyclamates while further tests are being done?

Another leading article (Nature, 224, 398; 1969) claims that cyclamates caused no "recorded hurt" during 15 years' use. Even if careful studies had been performed on a possible relation between cyclamate consumption and human malignancy (which we doubt), we would ask if the production of "recorded hurt" to humans during 15 years' use is a valid criterion for the safety of cyclamates or any food additive. While we feel that it is cvident to most of Nature's readers that this is not a valid criterion, it may not be so clear to readers of the lay press where accounts of this editorial have appeared. Nor, apparently, is it clear to the editors of Nature. Thus we feel bound to point out that it is oxtremely difficult to obtain convincing data on effects of food additives like cyclamates on human consumers. The reasons for this lie in the relatively low expected frequencies of induced tumours or mutations, and the likely long delay between exposure and effect, to say nothing of the difficulty of obtaining adequate controls. But low frequencies and long delays do not make the effects any less disastrous to those human guinea-pigs who are unfortunate enough to experience them.

We also note that Nature does not cite France as one of those countries that joined the anticyclamate bandwagon with precipitous and undignified haste. This is presumably because in that country the addition of eyclamates to food products has already been forbidden for some time. There was evidence in France at least 2 years ago of serious health hazards associated with cyclamates (see Le Monde, October 21, 1969). This evidence was not cited in Nature's editorial.

We would-with Nature-condemn US and British officials for the speed with which they reached their conclusions. But we would argue that these conclusions came 2 years too late. Perhaps there were some slow committees at work after all.

Yours faithfully,

W. A. Andersox

Edward N. Brody

Institut de Biologie Moléculaire,

Université de Genève,

1121 Genève 4,

Switzerland.

The 15 years for which cyclamates have been used was cited in contrast to the week it took to ban them; it was in no way implied that the past record of cyclamates necessarily justifics their future use. Nor was it implied that cyclamates are necessarily safe but merely that toxicological evidence can often be hard to interpret and needs to be weighed carefully, not in a panic.-Editor, Nature.

\section{University News}

Professor A. M. Gleason has been appointed the Hollis professor of mathematics and natural philosophy at Harvard University. He succeeds Professor J. H. van Vleck, who has retired.

Professor F. M. Carpenter has been appointed the Fisher professor of natural history at Harvard University in succession to Professor P. A. Mangelsdorf.

The title of professor of endocrine physiology has been conferred on Dr J. Lee, in respect of his post at Charing Cross Hospital Medical School, University of London.

\section{Appointments}

Dr A. Baker has been appointed the first director of the Hospital Advisory Service. Dr Baker, previously at Banstead Hospital and St Mary Abbots Hospital, has for the past year been on sccondment from the SouthWest Metropolitan Regional Hospital Board to the Department of Health and Social Security. 